\title{
EIF2AK2 wt Allele
}

National Cancer Institute

\section{Source}

National Cancer Institute. EIF2AK2 wt Allele. NCI Thesaurus. Code C51273.

Human EIF2AK2 wild-type allele is located within 2p22-p21 and is approximately $58 \mathrm{~kb}$ in length. This allele, which encodes interferon-induced, double-stranded RNA-activated protein kinase protein, plays a role in the regulation of protein synthesis. 